\title{
Number of Doses of Measles-Mumps-Rubeola Vaccine Applied in Brazil Before and During The COVID-19 Pandemic
}

Tércia Moreira Ribeiro da Silva ( $\nabla$ tercialud@gmail.com )

Universidade Federal de Minas Gerais

Ana Carolina Micheletti Gomide Nogueira de Sá

Universidade Federal de Minas Gerais

Ed Wilson Rodrigues Vieira

Universidade Federal de Minas Gerais

Elton Junio Sady Prates

Universidade Federal de Minas Gerais

Mark Anthony Beinner

Universidade Federal de Minas Gerais

Fernanda Penido Matozinhos

Universidade Federal de Minas Gerais

\section{Research Article}

Keywords: Measles-Mumps-Rubella Vaccine, Epidemiology, COVID-19, Brazil, Ecological Studies, Spatial Analysis

Posted Date: July 22nd, 2021

DOI: https://doi.org/10.21203/rs.3.rs-712618/v1

License: (c) (1) This work is licensed under a Creative Commons Attribution 4.0 International License.

Read Full License 


\section{Abstract \\ Background}

Due to the social isolation measures adopted in an attempt to mitigate the risk of transmission of SARSCoV-2, there has been a reduction in vaccination coverage of children and adolescents in several countries and regions of the world.

\section{Objective}

Analyze the number of doses of vaccine against Measles-Mumps-Rubeola (MMR) applied before and after the beginning of mitigation measures due to COVID-19 pandemic in Brazil.

\section{Methods}

Ecological study, with data from the National Immunization Program. The Mann-Whitney test evaluated differences between the median number of MMR vaccine doses applied in Brazilian regions, states and municipalities during April/2019 to March/2020 (before the beginning of mitigation measures) and April/2020 to September/2020 (after the start of mitigation measures). Spatial analysis identified clusters with a high percentage of reduction in the median of applied doses, and interpreted according to the Global Moran's Index (I). All analyzes considered the significance level of $5 \%$.

\section{Results}

There was a reduction in the median of doses applied in the Regions: North (-33.03\%), Northeast $(-43.49 \%)$ and South (-39.01\%). In States: Acre (-48.46\%), Amazonas (-28.96\%), Roraima (-61.91\%), Paraíba (-41.58\%), Sergipe (-47.52\%), Rio de Janeiro (-59.31\%) and Santa Catarina $(-49.32)(p<0.05)$. High-high type spatial clusters (reduction between 34.00 to $90.00 \%$ ) were formed in the five regions of Brazil (Moran's I $=0.055 ; p=0.01$ ).

\section{Conclusion}

A reduction in the number of MMR vaccine doses was evidenced as a possible effect by the restrictive actions of COVID-19 in Brazil.

\section{Background}

During the Coronavirus Disease Pandemic 2019 (COVID-19), national and international health agencies recommended that immunization services to continue, uninterrupted, their activities, due to the possibility 
of a return of vaccine-preventable diseases, controlled or eliminated, in response to low vaccination coverage [1]. However, studies have shown that, due to the social isolation measures adopted in an attempt to mitigate the risk of transmission of SARS-CoV-2, the etiological agent of COVID-19 [2, 3], there has been a reduction in vaccination coverage of children and adolescents in several countries and regions of the world $[4,5]$.

The impact on vaccine coverage was not an exclusive event of the COVID-19 pandemic. Studies conducted after catastrophes and epidemics that occurred in human history also pointed to a decline in vaccination coverage as a response to the reduction in the population's supply and access to health services [6]. After the Ebola outbreak that occurred in Liberia, Sierra Leone and Guinea, in West African countries, starting in 2013 and extending to 2015, there was a 25\% decline in measles vaccination coverage, favoring the formation of pockets of susceptible individuals in these countries [6, 7]. In response to low vaccination coverage, since 2017, two years after the end of the Ebola outbreak, these countries are facing rising measles cases and deaths [7]. Recently, Liberia and the Democratic Republic of Congo, located in Central Africa, face the collapse of health services due to the overlapping of cases and deaths from COVID-19, measles and Ebola $[6,8]$.

Difficult access to immunization services and child malnutrition are factors that act synergistically, placing communities living in a situation of social vulnerability more susceptible to the development of severe forms and death as a result of measles [9]. Even with the widespread diffusion of the MeaslesMumps-Rubella vaccine (MMR vaccine) in 2019, the world's measles rates reached the highest level in the last two decades $[9,10]$. It is estimated that in 2018 , more than 140,000 people died from measles, with the majority of deaths reported in underdeveloped countries, affecting mainly malnourished children [10]. In this sense, health strategies and policies aimed at improving MMR vaccine coverage indicators are needed, especially in low- and middle-income countries[9].

In Brazil, in 2018, two years after receiving certification for the elimination of measles in the Americas [11], 10,346 cases of the disease were confirmed, resulting in the loss of certification as a "measles virusfree country" [12]. In 2019 and 2020, there were 20,901 and 8,448 measles cases confirmed, respectively and by April 2021, another 318 cases were confirmed [12]. The recently reported cases of measles can be explained by the progressive drop in the coverage of the MMR vaccine in Brazil over the last decade and by the formation of clusters of susceptible individuals in the States of Acre, Amazonas, Pará, Amapá, located in the North region, and in the State of Maranhão, located in the Northeast region of the country [13].

Given the immense size of Brazil and the challenge experienced by the COVID-19 pandemic, this study advances by showing the inequalities in coverage of the MMR vaccine in different locations in the country, pointing to the formation of pockets of individuals susceptible to measles, rubella and mumps. Using the results and lessons learned from this study, it will be possible to improve health strategies and policies thus working at substantially improving the country's immunization indicators for these areas. 
Regional inequalities in vaccine coverage in Brazil $[13,14]$, can be attributed, in part, to differences in investments in the health sector in the North and Northeast regions when compared to other Brazilian regions, which culminated in the precariousness of the nationally mandated Primary Healthcare Services (Atenção Primaria - AB), responsible for offering free immunization through the National Immunization Program (PNI) [15]. Considering that the historical reduction in MMR vaccine coverage rates in Brazil [16, 17], may have been aggravated by the sanitary measures adopted due to the COVID pandemic-19 and that in Brazil the distribution of health services and the allocation of health resources is known to be heterogeneous [18], this study aims to analyze the number of doses of the MMR vaccine applied before and after the beginning of measures of social distancing in response to the pandemic of COVID-19 in the municipalities, states and regions of Brazil. In addition, this study aims to identify, through spatial analysis, clusters formed by municipalities with a high contingent of individuals susceptible to measles.

\section{Methods}

\section{Study design}

This was an ecological study, with data taken from the Brazilian National Immunization Information Program System (SI-PNI), available at http://sipni.datasus.gov.br/. The SI-PNI provides the number of doses of vaccines applied monthly throughout the country.

\section{Data collection}

The data collected refer to the number of doses of the MMR vaccine administered in the period from April 2019 to December 2020. Data extraction was performed by the number of doses applied monthly to the target population over the period: children aged 12 months (first dose) and 9-year-old children (second dose).

\section{Variables}

The independent variable was the number of doses applied. The independent variables were geographical, including the five regions of the country (North, Northeast, Central, Southeast and South), the 27 States of the Federation which are comprised of 5,568 Brazilian municipalities.

\section{Statistical analysis}

First, the doses of the MMR vaccine applied before (April 2019 to March 2020) and after the beginning of social distancing measures in Brazil (April to September 2020) in the 27 states were added. Next, the differences between the median number of doses applied before and after social distancing measures were evaluated by the Mann-Whitney $U$ test, considering the interquartile range (IQR) and the significance level of $5 \%$. The percentage of variation of the median doses applied was estimated using the equation:

[(median of doses applied by States before social distancing measures-median doses applied by State after social distancing measures) / median of doses applied by States before social distancing measures $x$ 100]. 
These analyzes were processed using the Statistical Package for Social Sciences software (IBM-SPSS, v.19, IBM, Chicago, IL).

For the general spatial analysis, the percentage variation of the median doses of the MMR vaccine was considered, before and after the beginning of social distancing measures in Brazil in each Brazilian municipality. The percentage variation of the median of applied doses was estimated using the equation previously mentioned.

Techniques for spatial analysis of area data were used considering the digital grids of Brazilian municipalities, using two Geographic Information System (GIS) programs. To examine the existence of a spatial correlation of the median reduction of doses of the MMR-Triple Viral vaccine, the Global Moran's Index (I) was calculated, which ranges from -1 to +1 , with positive values (between 0 and +1 ) indicating direct correlation and negative values, between 0 and -1 (an inverse correlation). Spatial correlation is interpreted according to the $I$ and can be weak $(I<0.3)$, moderate $(I \geq 0.3 ;<0.7)$ or strong $(I>0.7)[19]$.

From the cartographic base of the Brazilian municipalities acquired on the IBGE website, cartograms were created for the presentation of clusters with statistical significance $(p<0.05)$. The Moran Eigenvector Maps (MEM) show the high-high spatial clusters (red color) with statistical significance, formed by municipalities with a high percentage reduction in the median of applied doses of the MMR vaccine and surrounded by municipalities with the same trend. Municipalities that did not present significant spatial correlation $(p>0.05)$ or that formed spatial clusters of low-low, low-high or high-low types, were not represented on the map. The regions of the country, namely: North, Northeast, Central, Southeast and South, will be represented in the cartogram with different shades of gray.

In this study, the $95 \%$ of Global Moran I level of significance was considered after 999 permutations [19], that is, the areas with statistically significant spatial correlation were those whose $p$-value was less than or equal to 0.05 after 999 random permutations. For these spatial analyses, the following software was used: Spatial Analysis Laboratory, University of Illinois, Urbana Champaign, United States (GeoDa 0.9.9.10) and TerraView, version 4.1.0.

\section{Ethical aspects}

Due to the nature of the study of using freely accessible data, it was not necessary to submit the present study to the Research Ethics Committee, in accordance with Resolution 466/2012 of the National Health Council [20].

\section{Results}

From April 2019 to September 2020, 25,717,742 doses of the MMR vaccine were applied throughout Brazil (46.55\% after the beginning of the social distancing measures). In the period before measurements, the median number of doses applied was 1,645,527 (IQR $=794,667-2,176,287)$. During this period of evaluation, the median dropped to 934,991 (IQR: 757,329-1,260,678), equivalent to a reduction of $43.17 \%$. 
Of the five regions of the country, the North, Northeast and South showed a statistically significant reduction in the median number of doses applied during the duration of the public health emergency measures. Among the states, seven showed a statistically significant reduction, ranging from $47.52 \%$ in Sergipe, to $64.91 \%$ in Roraima (Table 1 ). 
Table 1

Median and percentage change in the median number of Triple Viral vaccines (MMR) administered.

\begin{tabular}{|c|c|c|c|c|}
\hline States and Regions & $\begin{array}{l}\text { April/19 - March/20 } \\
\text { Median (P25 - P75) }\end{array}$ & $\begin{array}{l}\text { April/20 - } \\
\text { September/20 } \\
\text { Median (P25 - P75) }\end{array}$ & $\begin{array}{l}\text { Variation } \\
(\%)\end{array}$ & $p^{*}$ \\
\hline Brazil & $\begin{array}{l}1.645 .527 \text { (794.667- } \\
2.176 .287)\end{array}$ & $\begin{array}{l}934.991(757.329- \\
1.260 .678)\end{array}$ & -43.17 & 0.180 \\
\hline North & $8.249(5.352-21.528)$ & $5.524(2.398-13.289)$ & -33.03 & 0.007 \\
\hline Acre & $3.725(2.313-5.795)$ & $1.920(1.749-2.283)$ & -48.46 & 0.007 \\
\hline Amapá & $4.210(1.887-7.736)$ & $1.811(889-3.698)$ & -56.97 & 0.067 \\
\hline Amazonas & $24.865(21.693-29.212)$ & $17.662(10.487-18.842)$ & -28.96 & 0.002 \\
\hline Pará & $70.60(26.514-104.196)$ & $47.808(30.658-93.943)$ & -32.31 & 0.682 \\
\hline Rondônia & $9.853(6.993-14.417)$ & 7.309 (6.554-9.199) & -25.81 & 0.250 \\
\hline Roraima & $8.164(7.188-8.527)$ & $2.864(2.082-4.460)$ & -64.91 & 0.000 \\
\hline Tocantins & $6.519(5.352-11.474)$ & $5.471(4.786-6.606)$ & -16.07 & 0.180 \\
\hline Northeast & $31.180(16.254-49.693)$ & $17.618(9.827-42.954)$ & -43.49 & 0.009 \\
\hline Alagoas & $24.748(12.334-38.047)$ & $12.669(8.606-80.190)$ & -48.80 & 0.553 \\
\hline Bahia & $72.075(46.428-170.581)$ & $62.320(52.049-82.323)$ & -13.53 & 0.494 \\
\hline Ceará & $49.394(25.703-74.028)$ & $38.333(26.499-52.847)$ & -22.39 & 0.494 \\
\hline Maranhão & $41.476(25.737-72.172)$ & $25.885(14.096-37.853)$ & -37.58 & 0.063 \\
\hline Paraíba & $18.047(12.741-39.194)$ & $10.543(8.397-12.917)$ & -41.58 & 0.010 \\
\hline Pernambuco & $45.644(30.999-100.597)$ & $41.979(33.530-52.866)$ & -8.03 & 0.553 \\
\hline Piauí & $22.437(9.216-37.044)$ & $12.136(8.894-14.780)$ & -45.90 & 0.125 \\
\hline $\begin{array}{l}\text { Rio Grande do } \\
\text { Norte }\end{array}$ & $14.910(8.979-31.871)$ & $10.454(6.909-26.816)$ & -29.89 & 0.437 \\
\hline Sergipe & 14.318(8.395-21.643) & 7.513(7.040-8.925) & -47.52 & 0.041 \\
\hline Central & $17.733(11.175-30.369)$ & $13.181(11.255-20.263)$ & -25.66 & 0.075 \\
\hline Distrito Federal & $16.022(10.382-26.444)$ & $11.968(10.298-18.516)$ & -25.29 & 0.437 \\
\hline Goiás & $26.599(16.504-50.864)$ & $22.884(19.098-26.081)$ & -13.96 & 0.553 \\
\hline
\end{tabular}

Note: $\mathrm{P}=$ Percentile; * Mann-Whitney test (difference between medians).

Source: National Immunization Program, Brazil, April 2019 to March 2020 and April 2020 to

September 2020.Source: National Immunization Program, Brazil, April 2019 to March 2020 and April 2020 to September 2020. 


\begin{tabular}{|c|c|c|c|c|}
\hline \multirow[t]{2}{*}{ States and Regions } & \multirow{2}{*}{$\begin{array}{l}\text { April/19 - March/20 } \\
\text { Median (P25 - P75) }\end{array}$} & \multirow{2}{*}{$\begin{array}{l}\text { April/20 - } \\
\text { September/20 } \\
\text { Median (P25 - P75) }\end{array}$} & \multirow[t]{2}{*}{$\begin{array}{l}\text { Variation } \\
\text { (\%) }\end{array}$} & \multirow[t]{2}{*}{$p^{\star}$} \\
\hline & & & & \\
\hline Mato Grosso & $12.770(9.150-21.261)$ & $12.194(10.183-15.190)$ & -25.84 & 0.180 \\
\hline $\begin{array}{l}\text { Mato Grosso do } \\
\text { Sul }\end{array}$ & $12.769(9.149-21.260)$ & $12.193(10.182-15.190)$ & -4.51 & 0.682 \\
\hline Southeast & $\begin{array}{l}106.908(35.384- \\
220.958)\end{array}$ & $\begin{array}{l}76.034(35.558- \\
177.384)\end{array}$ & -28.87 & 0.351 \\
\hline Espírito Santo & $21.798(19.825-32.589)$ & $25.013(18.680-46.157)$ & 14.74 & 0.892 \\
\hline Minas Gerais & $\begin{array}{l}110.574(91.922- \\
212.637)\end{array}$ & $\begin{array}{l}140.480(95.501- \\
176.163)\end{array}$ & 27.04 & 0.750 \\
\hline Rio Janeiro & $89.087(41.172-129.471)$ & $36.248(34.224-37.285)$ & -59.31 & 0.018 \\
\hline São Paulo & $\begin{array}{l}246.595(209.330- \\
662.975)\end{array}$ & $\begin{array}{l}226.283(166.472- \\
371.318)\end{array}$ & -8.23 & 0.335 \\
\hline South & $54.250(41.475-93.080)$ & $33.084(27.607-54.533)$ & -39.01 & 0.007 \\
\hline Paraná & $81.645(44.428-164.329)$ & $57.506(51.821-66.180)$ & -29.56 & 0.750 \\
\hline Santa Catarina & $56.141(36.571-93.080)$ & $28.447(26.736-31.991)$ & -49.32 & 0.007 \\
\hline $\begin{array}{l}\text { Rio Grande do } \\
\text { Sul }\end{array}$ & $43.931(26.408-71.409)$ & $30.522(25.086-34.712)$ & -30.52 & 0.151 \\
\hline \multicolumn{5}{|c|}{$\begin{array}{l}\text { Note: P = Percentile; * Mann-Whitney test (difference between medians). } \\
\text { Source: National Immunization Program, Brazil, April } 2019 \text { to March } 2020 \text { and April } 2020 \text { to } \\
\text { September } 2020 \text {.Source: National Immunization Program, Brazil, April } 2019 \text { to March } 2020 \text { and April } \\
2020 \text { to September } 2020 \text {. }\end{array}$} \\
\hline
\end{tabular}

Weak spatial autocorrelation $(I=0.055 ; p=0.01)$ and the presence of High-High spatial clusters were identified, formed by 262 municipalities that presented a reduction in the median of applied doses between 34 and 90\%, 88 of which were located in the North Region, 107 in the Northeast region, 41 in the Southeast region and 26 in the South region (Fig. 1).

\section{Discussion}

The COVID-19 pandemic resulted in a reduction in the number of applied doses of the MMR vaccine as a possible effect of the restrictive actions of COVID-19. The North, Northeast and South regions and the States of Acre, Amazona, Roraima, Paraiba, Sergipe, Rio de Janeiro and Santa Catarina showed a significant reduction in the median of MMR vaccine doses applied during the period that recommendations for social distancing were put in place in Brazil. High-High spatial clusters were formed by municipalities located mostly in the Northeast and North regions of the country. 
National and international studies attributed a reduction of the population's demand for health services, with a consequent drop in vaccination coverage, to the restrictive mitigation measures adopted during the COVID-19 pandemic $[1,5,21,22]$. However, there has been an observed trend in a decline in vaccine doses applied in Brazil over the last two decades [22], especially those immunobiologicals recommended in early childhood $[13,23]$. Contextual and individual factors that have been cited in recent studies $[15,22]$ have attributed the decline based on vaccination coverage including the lack of planning by the Brazilian National Universal Healthcare System (SUS), social and cultural aspects effecting vaccination acceptance, logistical difficulties cited by the PNI in offering several routine vaccines as part of the national vaccine schedule, anti-vaccination movements, and inconsistencies in the availability of immunobiologicals offered by Primary Healthcare services.

In this study, three of the five Brazilian regions demonstrated a statistically significant reduction in the median of doses of the MMR vaccine applied during the period of social distancing measures. This scenario, added to the drop in vaccination coverage rates in recent years, point to a problem for collective immunity and the risk of outbreaks caused by measles $[14,23]$. Furthermore, it is worth noting that the regional inequalities in vaccination coverage in Brazil has favored the formation of pockets of susceptible individuals $[13,23,24]$.

Between 2015 and October 2018, Brazil experienced a significant drop in MMR vaccine coverage, from 96.1 to $86.7 \%$ and, only after the national vaccination campaign, in September 2018, did it reach the $95.0 \%$ target. These low vaccination coverage indicators, added to measles cases imported from Venezuela, triggered an epidemic of the disease that affected several Brazilian states, mainly states in the Northern regions [25].

A study that evaluated the availability of the MMR vaccine in Brazil from 2013 to 2014 indicated that the immunization services located in the North region had a inefficient structure for immunization actions and demonstrated a lower frequency of vaccine availability [15]. The lack of vaccine in the Northern region, even during short period of time, incurs a lost opportunity for vaccination and can compromise the achievement of vaccination coverage goals, increasing the number of susceptible individuals in this region [15].

The lower frequency of availability of the MMR vaccine, on top of the logistical and structural problems of the $A B$ services in the Northern region, may have contributed to the formation of clusters with a higher percentage reduction in the coverage of the MMR vaccine in this region. Furthermore, it is noteworthy that measles is one of the most contagious infectious diseases known [26], making it necessary to adopt emergency strategies for vaccinating communities that formed clusters with a significant reduction in immunization coverage during the COVID-19 pandemic period. This strategy aims to reduce the chances of overlapping cases of measles and COVID-19, which could favor the collapse of healthcare services in these regions.

Furthermore, the collapse of health services in some states in the North and Northeast regions, due to the increasing demand for hospital beds for patients with COVID-19, may have contributed to the reduction in 
the population's demand for immunization services in these regions [27, 28]. Strategies to contain the pandemic in states and regions of Brazil were also not uniform, which may explain the percentage variations in the median of applied doses of the MMR vaccine, from $47.52 \%$ in the State of Sergipe ( $p=$ $0.041)$ to $64.91 \%$ in the State of Roraima $(p=0.000)$. While in some locations, the response to the epidemic phase of acceleration of the number of cases and deaths from COVID-19 was the mitigation by means of social distancing, other locations resorted to the strategy of total confinement, that is suspending all non-essential activities and limiting the circulation of people [29, 30].

In Brazil, more than a year after the first case of COVID-19, the country continues to lag behind many developing countries in an effort to immunize its population against COVID-19 [31] and many public health officials agree that long-term social isolation strategies will continue for several years to come [32]. Under this scenario, it is necessary to adopt health strategies and policies that ensure the population's universal access to immunization programs. The consequences of a lack of access would means living with the overlapping cases and deaths from COVID-19 with other infectious diseases, such as measles, rubella and mumps.

\section{Limitations and study strengths}

One of the weaknesses of the present study was in relation to the intrinsic limitations of studies that use secondary data, in addition to the fact that the available data were not specifically collected to answer the questions proposed in this research. Another point that deserves to be highlighted was the possible influences related to the standardization and quality of filling in the SI-PNI records, which may be subject to information bias. However, in this study, the SI-PNI registered population data was used during the study period, and the generalization of these results is relatively safe for national estimates. Also, to control biases, methodological rigor was taken into account during all of the stages of the study execution.

\section{Conclusions}

The COVID-19 pandemic resulted in a reduction in the number of applied doses of the MMR vaccine as a possible effect of the restrictive actions of COVID-19. In Brazil, few studies have evaluated the impact of the COVID-19 pandemic on the vaccination of children and adolescents, and this is the first study in the country to consider the MMR vaccine. The results of this work may support public health policies to guarantee immunization strategies against measles, rubella and mumps in the country, even during the current epidemic phase, which continues to result in increases in the number of COVID-19 cases in Brazil. In this sense, this work may point out priority areas for which public health policies and health strategies should be adopted to improve immunization indicators, in order to prevent the spread of potentially vaccine-preventable infectious diseases.

\section{List Of Abbreviations}


Coronavirus Disease Pandemic 2019 - COVID-19

Measles-Mumps-Rubella vaccine - MMR vaccine

Global Moran's Index - I

Moran Eigenvector Maps - MEM

National Immunization Program - PNI

Interquartile range - IQR

Brazilian National Immunization Information Program System - SI-PNI

\section{Declarations}

\section{Ethics approval and consent to participate}

Due to the nature of the study of using freely accessible data, it was not necessary to submit the present study to the Research Ethics Committee, in accordance with Resolution 466/2012 of the National Health Council.

\section{Consent for publication}

Not Applicable.

\section{Availability of data and materials}

The datasets used and/or analysed during the current study available from the corresponding author on reasonable request.

\section{Competing interests}

The authors declare that they have no competing interests.

\section{Funding}

None.

\section{Authors' contributions}

TMRS: conception, worked on study design, analysis and interpretation of data, co-wrote this manuscript, critical content review and approval of the final version.

ACMGNS: worked on study design, analysis and interpretation of data, co-wrote this manuscript, critical content review and approval of the final version. 
EJSP: interpretation of data, co-wrote this manuscript, critical content review and approval of the final version.

EWRV: data interpretation, co-wrote this manuscript, critical content review and approval of the final version.

MAB: data interpretation, co-wrote this manuscript, critical review of content and approval of the final version.

FPM: data interpretation, co-wrote this manuscript, critical review of content and approval of the final version.

\section{Acknowledgements}

We would like to thank NUPESV - Center for Studies and Research in Vaccination - for their support in carrying out this study and to the National Immunization Program for providing the data.

\section{Authors' information (optional)}

TMRS; ACMGNS; EJSP; EWRV; MAB; FPM: School of Nursing, Universidade Federal de Minas Gerais, Belo Horizonte, Brazil.

ACMGNS; FPM: Graduate Programa in Nursing, School of Nusing, Universidade Federal de Minas Gerais, Belo Horizonte, Brazil.

\section{References}

1. Saxena $\mathrm{S}$, Skirrow $\mathrm{H}$, Bedford $\mathrm{H}$. Routine vaccination during covid-19 pandemic response. BMJ 2020;369. https://doi.org/10.1136/bmj.m2392.

2. Da Silva LLS, Lima AFR, Polli DA, Razia PFS, Pavão LFA, De Hollanda Cavalcanti MAF, et al. Social distancing measures in the fight against covid-19 in brazil: Description and epidemiological analysis by state. Cad Saude Publica 2020;36. https://doi.org/10.1590/0102-311X00185020.

3. Brasil. Portaria No 1.565, de 18 de junho de 2020. Brasil: Publicado em: 19/06/2020 | Edição: 116 | Seção: 1 | Página: 64; 2020.

4. Chandir S, Siddiqi DA, Mehmood M, Setayesh H, Siddique M, Mirza A, et al. Impact of COVID-19 pandemic response on uptake of routine immunizations in Sindh, Pakistan: An analysis of provincial electronic immunization registry data. Vaccine 2020;38:7146-55. https://doi.org/10.1016/j.vaccine.2020.08.019.

5. Mansour Z, Arab J, Said R, Rady A, Hamadeh R, Gerbaka B, et al. Impact of COVID-19 pandemic on the utilization of routine immunization services in Lebanon. PLoS One 2021;16. https://doi.org/10.1371/journal.pone.0246951. 
6. Masresha BG, Luce R, Weldegebriel G, Katsande R, Gasasira A, Mihigo R. The impact of a prolonged ebola outbreak on measles elimination activities in Guinea, Liberia and Sierra Leone, 2014-2015. Pan Afr Med J 2020;35:8. https://doi.org/10.11604/pamj.supp.2020.35.1.19059.

7. Elston JWT, Cartwright C, Ndumbi P, Wright J. The health impact of the 2014-15 Ebola outbreak. Public Health 2017;143:60-70. https://doi.org/10.1016/j.puhe.2016.10.020.

8. Roberts $L$. Why measles deaths are surging - and coronavirus could make it worse. Nature 2020;580:446-7. https://doi.org/10.1038/d41586-020-01011-6.

9. Measles \& Rubella Initiative. Measles and Rubella Strategic Framework 2021-2030. 1st ed. Genebra: 2021.

10. Nachega JB, Mbala-Kingebeni P, Otshudiema J, Zumla A, Tam-Fum JJM. The colliding epidemics of COVID-19, Ebola, and measles in the Democratic Republic of the Congo. Lancet Glob Heal 2020;8:e991-2. https://doi.org/10.1016/S2214-109X(20)30281-3.

11. O'Connor P, Jankovic D, Muscat M, Ben-Mamou M, Reef S, Papania M, et al. Measles and rubella elimination in the WHO Region for Europe: progress and challenges. Clin Microbiol Infect 2017;23:504-10. https://doi.org/10.1016/j.cmi.2017.01.003.

12. Brasil, Ministério da Saúde. Monitoramento dos casos de arboviroses urbanas causados por vírus transmitidos pelo mosquito Aedes (dengue, chikungunya e zika), semanas epidemiológicas 1 a 16, 2021. Brasília: 2021.

13. Arroyo LH, Ramos ACV, Yamamura M, Weiller TH, Crispim J de A, Cartagena-Ramos D, et al. [Areas with declining vaccination coverage for BCG, poliomyelitis, and MMR in Brazil (2006-2016): maps of regional heterogeneity]. TT - Áreas com queda da cobertura vacinal para BCG, poliomielite e tríplice viral no Brasil (2006-2016): mapas da heterogen. Cad Saude Publica 2020;36:e00015619e00015619.

14. Césare N, Mota TF, Lopes FFL, Lima ACM, Luzardo R, Quintanilha LF, et al. Longitudinal profiling of the vaccination coverage in Brazil reveals a recent change in the patterns hallmarked by differential reduction across regions. Int J Infect Dis 2020;98:275-80.

https://doi.org/10.1016/j.ijid.2020.06.092.

15. Vieira EW, Pimenta AM, Montenegro LC, Silva TMR da. Estrutura e localização dos serviços de vacinação influenciam a disponibilidade da tríplice viral no Brasil. REME Rev Min Enferm 2020:e1325-e1325.

16. Pacheco FC, França GVA, Elidio GA, Domingues CMAS, de Oliveira C, Guilhem DB. Trends and spatial distribution of MMR vaccine coverage in Brazil during 2007-2017. Vaccine 2019;37:2651-5. https://doi.org/10.1016/j.vaccine.2019.04.019.

17. Lemos DRQ, Franco AR, de Sá Roriz MLF, Carneiro AKB, de Oliveira Garcia MH, de Souza FL, et al. Measles epidemic in Brazil in the post-elimination period: Coordinated response and containment strategies. Vaccine 2017;35:1721-8. https://doi.org/10.1016/j.vaccine.2017.02.023.

18. Pinho ECC, Da Cunha TAN, Lemos M, Ferreira GRON, Lourenção LG, Pinheiro HHC, et al. Acesso e acessibilidade na atenção primária à saúde no Brasil. Enferm Em Foco 2020;11:168-75. 
https://doi.org/10.21675/2357-707x.2020.v11.n2.3449.

19. Anselin L. Local Indicators of Spatial Association-LISA. Geogr Anal 2010;27:93-115. https://doi.org/10.1111/j.1538-4632.1995.tb00338.x.

20. Novoa PC orrei. R. What changes in research ethics in Brazil: resolution no. $466 / 12$ of the National Health Council. Einstein (Sao Paulo) 2014;12:vii-x. https://doi.org/10.1590/s167945082014 ed3077.

21. Sato APS. Pandemic and vaccine coverage: challenges of returning to schools. Rev Saude Publica 2020;54:115. https://doi.org/10.11606/s1518-8787.2020054003142.

22. Matos CC de SA, Barbieri CLA, Couto MT. Covid-19 and its impact on immunization programs: reflections from Brazil. Rev Saude Publica 2020;54:114. https://doi.org/10.11606/s15188787.2020054003042.

23. Buffarini R, Barros FC, Silveira MF. Vaccine coverage within the first year of life and associated factors with incomplete immunization in a Brazilian birth cohort. Arch Public Heal 2020;78:21. https://doi.org/10.1186/s13690-020-00403-4.

24. de Araújo Veras AAC, da Fonseca Lima EJ, Caminha MDFC, da Silva SL, de Castro AAM, Bernardo ALB, et al. Vaccine uptake and associated factors in an irregular urban settlement in northeastern Brazil: a cross-sectional study. BMC Public Health 2020;20:1152. https://doi.org/10.1186/s12889020-09247-7.

25. Rodríguez-Morales AJ, Suárez JA, Risquez A, Cimerman S, Valero-Cedeño N, Cabrera M, et al. In the eye of the storm: Infectious disease challenges for border countries receiving Venezuelan migrants. Travel Med Infect Dis 2019;30:4-6. https://doi.org/10.1016/j.tmaid.2019.05.014.

26. Guerra FM, Bolotin S, Lim G, Heffernan J, Deeks SL, Li Y, et al. The basic reproduction number (R0) of measles: a systematic review. Lancet Infect Dis 2017;17:e420-8. https://doi.org/10.1016/S14733099(17)30307-9.

27. Lemos DRQ, D'angelo SM, Farias LABG, Almeida MM, Gomes RG, Pinto GP, et al. Health system collapse 45 days after the detection of COVID-19 in Ceará, Northeast Brazil: A preliminary analysis. Rev Soc Bras Med Trop 2020;53:1-6. https://doi.org/10.1590/0037-8682-0354-2020.

28. De Souza Noronha KVM, Guedes GR, Turra CM, Andrade MV, Botega L, Nogueira D, et al. The COVID19 pandemic in Brazil: Analysis of supply and demand of hospital and ICU beds and mechanical ventilators under different scenarios. Cad Saude Publica 2020;36:115320. https://doi.org/10.1590/0102-311x00115320.

29. Szylovec A, Umbelino-Walker I, Cain BN, Ng HT, Flahault A, Rozanova L. Brazil's actions and reactions in the fight against COVID-19 from January to March 2020. Int J Environ Res Public Health 2021;18:1-16. https://doi.org/10.3390/ijerph18020555.

30. Houvèssou GM, Souza TP de, Silveira MF da. Medidas de contenção de tipo lockdown para prevenção e controle da COVID-19: estudo ecológico descritivo, com dados da África do Sul, Alemanha, Brasil, Espanha, Estados Unidos, Itália e Nova Zelândia, fevereiro a agosto de 2020. 
Epidemiol e Serv Saude Rev Do Sist Unico Saude Do Bras 2021;30:e2020513. https://doi.org/10.1590/S1679-49742021000100025.

31. Hannah Ritchie, Esteban Ortiz-Ospina, Diana Beltekian, Edouard Mathieu. Coronavirus (COVID-19) Vaccinations - Statistics and Research - Our World in Data 2021. https://ourworldindata.org/covidvaccinations (accessed March 29, 2021).

32. Guadalupe Medina M, Giovanella L, Bousquat A, Magalhães de Mendonça MH, Aquino R. Primary healthcare in times of COVID-19: what to do? Cad Saude Publica 2020;36. https://doi.org/10.1590/0102-311X00149720.

\section{Figures}

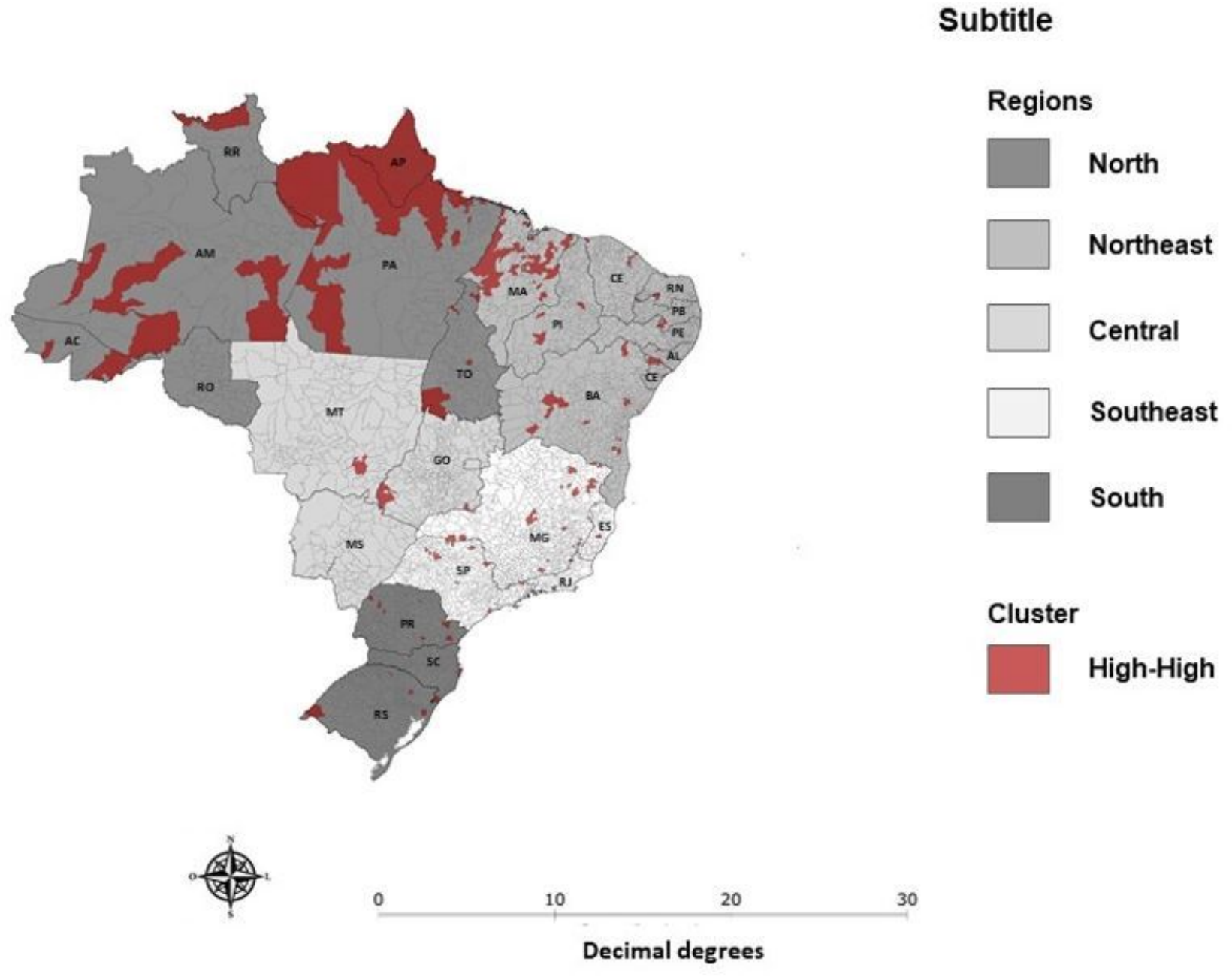

Figure 1

High-high spatial clusters with statistical significance. Source: National Immunization Program, Brazil, April 2019 to March 2020 and April 2020 to September 2020. 